\title{
PRIORITIES IN SEED PATHOLOGY RESEARCH
}

\author{
S.T. NAMETH \\ Dept. of Plant Pathology, The Ohio State University, Columbus, OH, 43210, USA.
}

\begin{abstract}
Seed pathology as a subdisipline of plant pathology is relatively new. Paul Neergard is considered the father of seed pathology. Recent developments in the area of seed pathology technology allow for more ecofriendly seed treatments and more reliable seed health testing. Due to economics and new interest in environmental issues, research into the viability of biological seed treatments is becoming more common. The use of sophisticated DNA amplification technologies allows for the detection of seedborne pathogens that might go undetected using more conventional means. These types of research will be fundamental in guaranteeing seed health quality standards and achieving phytosanitary requirements throughout the world in the new millennium.
\end{abstract}

Key Words: seedborne pathogens, pathogen detection, seed treatments, PCR, DNA amplification

\section{PRIORIDADES NA PESQUISA EM PATOLOGIA DE SEMENTES}

RESUMO: A patologia de sementes é uma área relativamente nova da Fitopatologia. Paul Neergaard é considerado o pai da patologia de sementes. O desenvolvimento de técnicas, nessa área, permite a realização de tratamentos de sementes menos agressivos ao ambiente e a execução de testes de sanidade mais confiáveis. Devido ao maior interesse nos aspectos econômicos e ambientais, as pesquisas relacionadas ao tratamento biológico de sementes estão se tornando mais comuns. O uso de tecnologias sofisticadas de amplificação do DNA permite a detecção de patógenos nas sementes, de maneira mais sensível que os métodos convencionais. Essas pesquisas serão fundamentais para garantir padrões elevados de sanidade de sementes e o melhor atendimento das exigências do consumidor, em todo o mundo, no próximo milênio.

Descritores: sementes, patógenos, tratamento de sementes, PCR, amplificação de DNA

\section{INTRODUCTION}

According to Agarwal \& Sinclair (1997), seed pathology may be defined as the study of seedborne disease and pathogens. It includes studies on the mechanisms of infection, seed transmission, the role of seedborne inocula in disease development, techniques for the detection of seedborne pathogens and nonpathogens, seed certification standards, deterioration due to storage fungi, mycotoxins, and mycotoxicoses, and control of seedborne inocula. Seed pathology includes the study of diseases and deterioration caused by bacteria, fungi, nematodes, viroids, and viruses, and physiological and mechanical disorders.

The discipline of seed pathology as a subdiscipline of plant pathology is relatively new. Paul Neergaard is considered the father of seed pathology and, along with Mary Noble coined the term Aseed pathology in the 1940's (Agarwal \& Sinclair, 1997). Neergaard was one of the founding father and later served as Director of the Danish Government Institute of Seed Pathology for Developing Countries, Copenhagen, Denmark. From 1956 to 1974 Dr. Neergaard served as the Chairman of the Plant Disease Committee of the International Seed testing Association (ISTA). During his tenure as Chair of ISTA, he helped standardize methods for the detection of seed borne fungi. Neergaard (1977) authored a two-volume text entitled A Seed Pathology. This text has served as a reference and teaching standard for the science of seed pathology throughout the world (Agarwal \& Sinclair, 1997). This text focused on a wide variety of seed pathology issues, ranging from the economic significance of seedborne diseases to the assessment of seed borne inoculum. Although all of the areas of seed pathology discussed above were covered in this text, little mention was made of future research priorities.

This is not the case in a recent review article authored by Dennis McGee entitled Epidemiological Approach to Disease Management Through Seed 
Technology (McGee, 1995). In this comprehensive review, McGee states under the heading of a research priorities, a review of the literature on seed pathology over the period of 1982 - 1994 indicated that almost a quarter of approximately 2000 citations simply catalogue the presence of microorganisms on seed. McGee continues, a these purely descriptive commentaries do not address the potential for crop damage by planting diseased seeds or the management of seedborne diseases. The type of cataloging research McGee identified focuses more on fungi than it does on bacteria and viruses. $\mathrm{He}$ writes that more research should be conducted in the area of seedborne bacteria and virus detection and identification since this area has been neglected due to the lack of adequate assays. He also discusses the importance of research in the area of establishing research thresholds for seedborne diseases, for these thresholds will be fundamental if the management of seedborne disease is to be successful. McGee makes it very clear that cataloging pathogens associated with seed is important, however; determining how that pathogen affects the long-term economic establishment of the crop should be the ultimate goal.

Since the publication of McGee's review, we need to ask ourselves the question, a have the research priorities in seed pathology shifted to be more in line with what he (McGee) envisioned or are we still spending too much time cataloging seedborne microorganisms?

The purpose of this paper is to address the issue of research priorities associated with the science of seed pathology as they are today and to determine if these priorities will serve the needs of the seed industry in the next millennium. Since the discipline of seed pathology covers a wide variety of subjects and McGee's comprehensive review of the subject was published in 1995, only those research priorities in selected areas of the discipline will be discussed. The priorities discussed will also partly reflect this author's bias as a plant virologist.

\section{RESEARCH PRIORITIES IN SEED PATHOLOGY}

Seed Treatments: Treating seed in an effort to control seedborne and soilborne diseases has been employed since the middle of the 17th century when $>$ brining $=$ was used by farmers in the United Kingdom to control Bunt of wheat (Maude, 1996). Since then, a wide variety of chemical, biological, physical, and mechanical approaches have been used to eliminate pathogens from the internal and external portion of seeds, and to help protect seeds from soilborne pathogens (Neergaard, 1977; Agarwal \& Sinclair, 1997; Maude, 1996; McGee, 1995). Chemical fungicide treatments such as Captan and Thiram are still the most widely used products in the industry and research into better ways to apply and to reduce the effective rates of these chemicals must continue. Besides these popular topical fungicides, there is a wide range of systemic fungicides which help control seedborne disease and offer some disease control for the seedling; however, under conditions of high disease pressure, they may often fail (Wang \& Davis, 1997). Some of these chemicals have the potential to be harmful to the soil and non soil environment as well as carry the potential to be phytotoxic to the seed and the emerging seedling (Fatmi et al., 1991). As a result of this, more and more seed treatment research is examining the ability of ecofriendly methods of treating seed to control disease(s).

Hot water treatment of seed, acid treatments or other methods, continue to be a standard method of pathogen elimination in seed. These methods are more ecofriendly and effective compared to chemical treatments (particularly hot water) and effective; however, they can cause the loss of seed viability (Erdey et al., 1997; Nan et al., 1998).

Identifying, testing, and developing biological seed treatments appears to be an area where much research effort is occurring and will continue in the future. The use of naturally occurring beneficial fungi and bacteria to control other fungi and bacteria is not a new idea; however, due to the renewed interest in the environment and the establishment of worker protection standards, research in this area is going through a renaissance. There are a variety of biological control agents used to treat seeds that are currently in various stages of development (Callan et al., 1997). Among these are the common soil inhabiting bacterial genera Psedudomonas, Enterobacter, Erwina, and Bacillus. The fungi Trichoderma and Gleocladium along with the actinomycete Streptomyces are also being studied carefully as to their seed treatment efficacy. Recent work by Zhang et al. (1996) has shown that treating cotton (Gossypium hirsutum) seed with the G-4 and G-6 strains of Gleocladium virens and the GB03 and GB07 strains of Bacillus subtilis suppress the incidence and the severity of Fusarium Wilt of cotton (Gossypium hirsutum) in soil infested with Fusarium 
oxysporium f. sp. vasinfectum and Meloidogyne incognita under greenhouse conditions. Milus \& Rothrock (1997) showed that treating winter wheat seeds with three bacterial strains reduced the incidence of Pythium root rot in growth chamber assays. However, when these same experiments were conducted under field conditions, the decline in the incidence of root rot was inconsistent. This is a common situation associated with many biofungicides and is discussed in detain in a variety of publications (Agarwal \& Sinclair, 1997; Maude, 1996).

As discussed by Callan et al. (1997), for a biological seed treatment to be effective, many factors have to fall in place. The inoculum density of the biocontrol agent must be adequate to suppress disease under field conditions and high levels of disease pressure. The formulation of the biocontrol agent must be one that allows for an adequate shelf life and it must be compatible with other biocontrol agents as well as chemical seed and soil treatments.

Future research should focus on finding new and more efficient biocontrol based seed treatments as well as refining and increasing the efficiency of the current crop of biocontrol agents.

Pathogen Detection and Identification: As stated earlier, McGee (1995) was concerned about the significance of indiscriminate cataloging of seedborne microorganisms and how that would over shadow the need to focus on true seedborne pathogens. More research needs to be conducted in the area of seedborne pathogen identification, particularly with bacteria and viruses. Many tests have been developed for the detection of seedborne fungi and have been reviewed extensively (Agarwal \& Sinclair, 1997; Maude, 1996). However, there are many seed - borne bacteria and viruses that lack adequate methods of detection (Agarwal \& Sinclair, 1997; McGee, 1995).

About $20 \%$ of the known plant viruses are transmitted through seeds of infected plants (Agarwal \& Sinclair, 1997) and in many cases the rate of transmission is very low. Jensen et al. (1991) reported that the seed transmission rate of maize chlorotic mottle spot virus was 17 in a total of 42,000 plants or $0.04 \%$. The seed transmission rate of maize dwarf mosaic was one seed in 22,189 (Mikel et al., 1984). With this incredibly low rate of seed transmission and the fact that plant viruses are strict obligate parasites, most conventional types of seed assays used to detect fungi and bacteria are useless. Serological-based seed assays, such as the enzyme linked immunosorbent assay (ELISA), continue to be used with some success for fungi and bacteria, (Lagerberg, 1996). However, they lack the specificity and sensitivity needed to detect many seedborne viruses (McGee, 1995).

With the introduction of DNA-based assays and polymerase chain reaction (PCR)-based assays, researchers have the ability to detect very minute amounts of a specific DNA sequence on the surface of or internal to a seed. Prossen et al. (1993) was able to detect the presence of a specific gene associated with the seed transmitted bacterium Pseudomonas syringe pv phaseolicola on the surface of a bean (Phaseolis vulgaris) seed. This bacterium had gone undetected using conventional selective media plating techniques. Recently, Sousa Santos et al. (1997) used PCR to detect the presence of Clavibacter michiganensis pv michiganensis in infested tomato seed lots. Kohnen et al. (1992) employed this technology to detect pea (Pisum sativum) seedborne mosaic virus.

The potential for using this type of technology for the detection of seedborne bacteria, and more so with seedborne viruses is significant. PCR-based detection research needs to continue and should become a vital part of the management of seedborne disease.

Other seed pathology research priorities that are important to mention, but were not discussed in detail, include the establishment of pathogen inoculum thresholds and the development of standardized assays that allow seed produced anywhere in the world to be monitored for some minimum level of health quality.

\section{CONCLUSIONS}

In conclusion, as technology advances and the ability to identify seed-transmitted pathogens becomes greater, the global production of diseasefree seed will become more and more of an issue. As with many biological entities, researchers have only started to examine the issue of seed-transmitted pathogens. With particular reference to plant viruses, there are probably as many hosts in which seed transmission takes place that have yet to be identified, as have been identified. As seed and plant propagation material moves from one part of the world to another overnight, it will be imperative that unwanted pathogens do not tag along, and if they do 
tag along, it must be at a pre-determined level that does not cause economic havoc for the end user.

Continued research into new methods of seed testing and pathogen management will need to be emphasized.

\section{REFERENCES}

AGARWAL, V.K.; SINCLAIR, J.B. Principles of seed pathology, 2.ed. Boca Raton: CRC, 1997. 538p.

CALLAN, N.W.; MATHRE, D.E.; MILLER, J.B.; VAVRINA, C.S. Biological seed treatments: factors involved in efficiency. Horticultural Science, v.32 p.179-183, 1997.

ERDEY, D.P.; MYCOCK, D.J.; BERJAK, P. The elimination of Fusarium moniliforme (Sheldon) infection in maize caryopses by hot water treatments. Seed Science and Technology, v.25, p.485-501, 1997.

FATMI, M.; SHAAD, N.W.; BOLKAN, H.A. Seed treatments for eradicating Clavibacter michiganensis subsp. michiganensis from naturally infected tomato seeds. Plant Disease, v.75, p.383-385, 1991.

JENSEN, S.G.; WYSONG, D.S.; BALL, E.M.; HIGLEY, P.M. Seed transmission of maize chlorotic mottle virus. Plant Disease, v.75 p.479-501, 1991 .

KOHNEN, P.D.; DOUGHERTY, W.G.; HAMPTON, R.O. Detection of pea seedborne potyvirus by sequence specific enzymatic amplification. v.37, p.253-258, 1992.

LAGERBERG, C. Comparison of polyclonal ELISA with the seed - blotter, fluorescence and agar plate methods for the detection and quantification of seed - borne Septoria nodorun in wheat. Seed Science and Technology, v.24, p.585-588, 1996.

MAUDE, R.B. Seedborne diseases and their control. Cambridge: CAB International, 1996. 280 p.

McGEE, D.C. Epidemological approach to disease mangement through seed technology. Annual Review of Phytopathology, v.33, p.445-466, 1995. p.445-466.
MIKEL, M.A.; D'ARCY, C.J.; FORD, R.E. Seed transmission of maize dwarf mosaic in sweet corn. Phytopathologishe Zeistschrift, v.110, p.185, 1984.

MILUS, E.A.; ROTHROCK, C.S. Efficacy of bacterial seed treatments for controlling Pythium root rot of winter wheat. Plant Disease, v.81, p.180-184, 1997.

NAN, Z.B.; HANSON, J.; YESHI, W.M. Effects of sulfuric acid and hot water treatments on seedborne fungi and germination of Stylosanthes hamata, S. quianensis and S. scabra. Seed Science and Technology, v.26, p.33-43, 1998.

NEERGARD, P. Seed pathology. New York: John Wiley, 1977. 839p.

PROSSEN, D,; HATZILOUKAS, E.; SHAAD, N.W.; PANOPOULOS, N.J. Specific detection of Pseudomonas syringae pv. phaseolicola DNA in bean seed by polymerase chain reaction: based amplification of a phaseotoxin gene region. Phtyopathlogy, v.83, p.965-970, 1993.

SOUSA - SANTOS M.; CRUZ, L.; NORSKOV, P.; RASMUSSEN, O.F. A rapid and sensitive detection of Clavibacter michiganensis subsp. michiganensis in tomato seeds by polymerase chain reaction. Seed Science and Technology, v.25, p.581-584, 1997.

WANG, H.; DAVIS, R.M. Susceptibility of selected cotton cultivars to seedling disease pathogens and benefits of chemical seed treatments. Plant Disease, v.81, p.1085-1088, 1997.

ZHANG, J.; HOWELL, C.R.; STARR, J.L. Suppression of Fusarium colonization of cotton roots and Fusarium wilt by seed treatments with Gliocladium virens and Bacillus subtilis. Biocontrol Science Technology, v.6, p.175-187, 1996.

Recebido para publicação em 10/07/98 Aceito para publicação em 03/08/98 